\title{
Protein and DNA Isolation from Aspergillus Niger as well as Ghost Cells Formation
}

\author{
Nawal Abd El-Baky ${ }^{1 \#^{*}}$, Mona M. Sharaf ${ }^{1}$, Eman Amer $^{1}$, Hoda Reda Kholef ${ }^{1}$, \\ Mohamed Zakaria Hussain ${ }^{2}$ and Amro A. Amara ${ }^{1 \#^{*}}$ \\ ${ }^{1}$ Protein Research Department, Genetic Engineering and Biotechnology Research Institute, City for Scientific Research and \\ Technological Applications, Universities and Research Center District, New Borg El-Arab, Alexandria, Egypt
}

${ }^{2}$ Department of Microbiology and Immunology, Faculty of Medicine, Tanta University, Tanta

${ }^{\# B}$ Both authors contributed equally to this study.

Received: 07 May, 2018; Accepted: 20 August, 2018; Published: 01 October, 2018

*Corresponding author: Amro Abd Al Fattah Amara, The head of the Protein Research Department, Genetic Engineering, and Biotechnology Research Institute, City for Scientific Research and Technological Applications, Universities and Research Center District, New Borg El-Arab, P.O. Box: 21934 Alex, Egypt, Tel: +203-4593422; Fax: +203-4593497; E-mail: amroamara@web.de

\begin{abstract}
Recently, a protocol for ghost cells preparations was introduced. It was given the name sponge-like protocol: Procaryotes, eucaryotes and virus were turned to ghost cells using such protocol. In this study, with slight modifications, Aspergillus niger ghost cells were prepared using the same protocol. Both the Minimum Inhibitory Concentration (MIC) and the minimum growth concentration (MGC) values for $\mathrm{H}_{2} \mathrm{O}_{2}, \mathrm{NaOH}, \mathrm{NaHCO}_{3}$ and SDS against A. niger were determined. Five different randomization experiments were conducted instead of the full Plackett-Burman design. During the ghost preparation steps, the released Protein and DNA were measured spectrophotometrically at $280 \mathrm{~nm}$ and $260 \mathrm{~nm}$, respectively. The quality of the prepared ghost cells were evaluated during the preparation steps using light microscope. Transmission electron microscope was used for evaluating the final steps. Protein and DNA electrophoresis were conducted to evaluate the quality of the released protein and DNA after each randomization experiment. The data obtained prove correct evacuation of the fungal cells from their cytoplasmic content during the successive steps. The study not only introduces a protocol for preparing ghost cells from Aspergillus niger but also enables the isolation of both of protein and DNA. The idea, the concept and the tools used in this study could establish a more sensitive method for protein and DNA isolation using any of four utilized chemical compounds. This proposes the same concept of enzyme-induced cell lysis which is based on minimizing the effect of used chemicals or enzymes. The study recommended extending the benefit of the sponge-like protocol from being a protocol for ghost cells preparation to DNA and protein isolation technique using the same concept.
\end{abstract}

Keywords: Aspergillus niger; ghost cells; DNA isolation; Protein isolation

\section{Introduction}

Aspergillus niger is one of the most commonly found fungi either in in/outdoor environments. It causes black mould diseases in foods as vegetables, grapes, apricots, onions, peanuts, etc. Some reports prove that it is responsible for producing some dangerous mycotoxins. A. niger is less likely to cause human disease than some other Aspergillus sp. One of the most famous diseases it causes to human is the Aspergillosis; a lung disease. It is one of the otomycosis causing fungi, resulting in ear pain, temporary hearing loss, and head pain etc. In severe cases, it causes damage to ear canal and tympanic membrane. In fact, most people breath in Aspergillus spores including A. niger every day. In most cases, it causes nothing for healthy individuals if entered in a little quantity $[1,2]$. However, it turns to be pathogenic in cases such as immunocomprimized patients, illness, lung disease, and if inhaled in large amount. One could conclude that weak or compromised immune system is the most claimed causative agent for $A$. niger pathogenesis as well as exposure to large amount of spores or continuous source that enable their accumulation in the body particularly the lung. A. niger spores could be found everywhere but one of the most dangerous sources is the dry grinded seeds where the spore will not be germinated and could by one or another way reach to our bodies as spore. Spores are more dangerous than vegetative cells except in case of mycotoxin-producing strains. A. niger is not harmful in all cases, it is also beneficial and can be used in different biotechnological applications such as in the citric acid production [3].

Evacuating microbes from their cytoplasmic content is a natural phenomenon [4]. Pores could be introduced to the microbial cells as a result of different mechanisms [4-8]. Such as the evacuation of the gram-negative bacteria by the bacteriophage infections [4]. The bacteriophage E lysis gene is used for evacuating the cells and turning them to ghosts by controlling its expression using heat sensitive promoter $[4,5$, 8-11]. Recently, the Sponge Like protocol was introduced [1215]. Its main concept is using active chemical compounds that could introduce pores in the microbes and degrade the DNA at concentrations which did not change the surface antigens or the 3D structure [13]. This enables evacuating gram-negative and gram-positive bacteria, eukaryotes and viruses [4, 12-14, 16-27]. 
In this study, A. niger representing the fungi was prepared as ghosts. In addition, the idea for using the Sponge Like protocol for releasing both of DNA and protein for various applications was established. Using such protocol based on using chemical compounds or enzymes, not only the ghost cells are produced but also both of DNA and protein are isolated.

\section{Materials and Methods}

\section{Fungal strain}

A. niger strain used in this study was kindly identified and obtained from Al-Azhar University Mycology Center (Cairo, Egypt).

\section{Cultivation Conditions}

The A. niger strain was cultivated in one litre flask contains $500 \mathrm{~mL}$ Sabouraud's dextrose broth at $28^{\circ} \mathrm{C}$ for 7 days at $150 \mathrm{rpm}$.

Determination of the MIC and MGC Values for $\mathrm{NaoH}$, SDS, $\mathrm{NaHCO}_{3}$ And $\mathrm{H}_{2} \mathrm{O}_{2}$

Standard broth microdilution susceptibility assay for determining the MIC values for each of $\mathrm{NaOH}, \mathrm{SDS}, \mathrm{NaHCO}_{3}$ and $\mathrm{H}_{2} \mathrm{O}_{2}$ was conducted $[13,14]$. The MIC value for each compound was calculated as well as the concentration which allows first fungal growth which is abbreviated as MGC (the concentration showing first growth after the MIC).

\section{Determination of the MIC and MGC values for $\mathrm{NaOH}$, SDS, $\mathrm{NaHCO}_{3}$ and $\mathrm{H}_{2} \mathrm{O}_{2}$}

Standard broth microdilution susceptibility assay for determining the MIC values for each of $\mathrm{NaOH}, \mathrm{SDS}, \mathrm{NaHCO}_{3}$ and $\mathrm{H}_{2} \mathrm{O}_{2}$ was conducted $[13,14]$. The MIC value for each compound was calculated as well as the concentration which allows first fungal growth which is abbreviated as MGC (the concentration showing first growth after the MIC).

\section{Randomization experiment}

Five experiments were conducted to map the best preparation conditions either during the cells cultivation or during the ghost cells preparation. The different variables were four chemical compounds representing SDS, H2O2, NaHCO3, and $\mathrm{NaOH}$, and three physical parameters represented as cultivation temperature, shaking rate during treatment, and the cultivation time. The seven variables were randomized according to the design in Table 1.

Table 1: The randomization experiments for ghost cells preparation including 7 variables in +1 or -1 .

\begin{tabular}{|c|c|c|c|c|c|c|}
\hline $\begin{array}{c}\text { Experiment } \\
\text { Number }\end{array}$ & NaOH & SDS & NaHCO $_{3}$ & $\mathbf{H}_{2} \mathbf{O}_{2}$ & $\begin{array}{c}\text { Shaking rate during } \\
\text { treatment }\end{array}$ & $\begin{array}{c}\text { Cultivation } \\
\text { time } \\
\text { temperature }\end{array}$ \\
\hline $\mathbf{1}$ & +1 & -1 & +1 & +1 & -1 \\
\hline $\mathbf{2}$ & +1 & +1 & +1 & -1 & -1 \\
\hline $\mathbf{4}$ & -1 & +1 & -1 & +1 & -1 \\
\hline $\mathbf{5}$ & +1 & -1 & -1 & +1 & -1 \\
\hline
\end{tabular}

Each variable of the four used chemical compounds was represented at two levels (high and low), which are donated by +1 (MIC) and -1 (MGC) as in Table 1 . The +1 in shaking conditions refers to shaking at $150 \mathrm{rpm}$ during the different treatments while -1 refers to static incubation during treatment, +1 in growth time represents cultivation for 10 days while -1 represents cultivation for 5 days, +1 in growth temperature refers to cultivation at $28^{\circ} \mathrm{C}$ while -1 represents cultivation at $25^{\circ} \mathrm{C}$.

The biomass of the different cultivation conditions was collected and washed gently by $0.5 \%$ saline and recentrifuged at $6000 \mathrm{rpm}$ for $10 \mathrm{~min}$. The supernatant was then discarded. $5 \mathrm{X}$ stock for each of $\mathrm{NaOH}, \mathrm{SDS}, \mathrm{NaHCO}_{3}$ and $2 \mathrm{X}$ stock for $\mathrm{H}_{2} \mathrm{O}_{2}$ were prepared from both +1 (MIC) and -1 (MGC), which were determined as mentioned above.

All the experiments were conducted in three steps. The first step contains $\mathrm{NaOH}, \mathrm{SDS}, \mathrm{NaHCO}_{3}$ where $1 \mathrm{ml}$ from each was added to $1 \mathrm{ml}$ water and finally $1 \mathrm{ml}$ of the fungal suspension $(0.5$ gm of the fungus mat/ml) was added to get a final concentration of each of $\mathrm{NaOH}, \mathrm{SDS}, \mathrm{NaHCO}_{3}$ equal to $1 \mathrm{X}$. The second step contains $\mathrm{H}_{2} \mathrm{O}_{2}$. The $\mathrm{H}_{2} \mathrm{O}_{2}$ was used as $2 \mathrm{X}$ and one $\mathrm{ml}$ of the fungal suspension was added to reach final concentration of $\mathrm{H}_{2} \mathrm{O}_{2}$ equal to $1 \mathrm{X}$.
After each treatment step, the supernatant was collected by centrifuging the fungus at $6000 \mathrm{rpm}$. After that, the fungal pellet was washed using $1 \mathrm{X}$ Phosphate Buffered Saline (PBS) (alternatively common saline solution can be used). In the third step, the cell pellets were washed using $60 \%$ Ethanol and left at room temperature. After each of the above washing steps and centrifugation the supernatant was preserved to determine the amount of the released protein and DNA.

\section{Fungal Cells Evaluation Using Light Microscope}

Fungal sample from each randomization experiment was examined by light microscope. The quality of the cells from each experiment has been determined based on the cellular structure as being either intact or deformed and then the overall fungal ghost quality is given as $\%$.

\section{Determination of the DNA Concentration}

The concentration of DNA in the supernatant after each step for each randomization experiment was determined by measuring the absorbance at $260 \mathrm{~nm}$. Quartz cuvette was used. An extinction $260=1$ corresponds to $50 \mu \mathrm{g}$ dsDNA mL ${ }^{-1}$ [28]. 


\section{Determination of the Protein Concentration}

Concentration of released protein from each step in each randomization experiment (the different supernatants) was determined using the spectrophotometer at $280 \mathrm{~nm}$. Quartz cuvette was used. The protein concentration was derived from Bovine Serum Albumin (BSA) standard curve (Figure 1) [15].

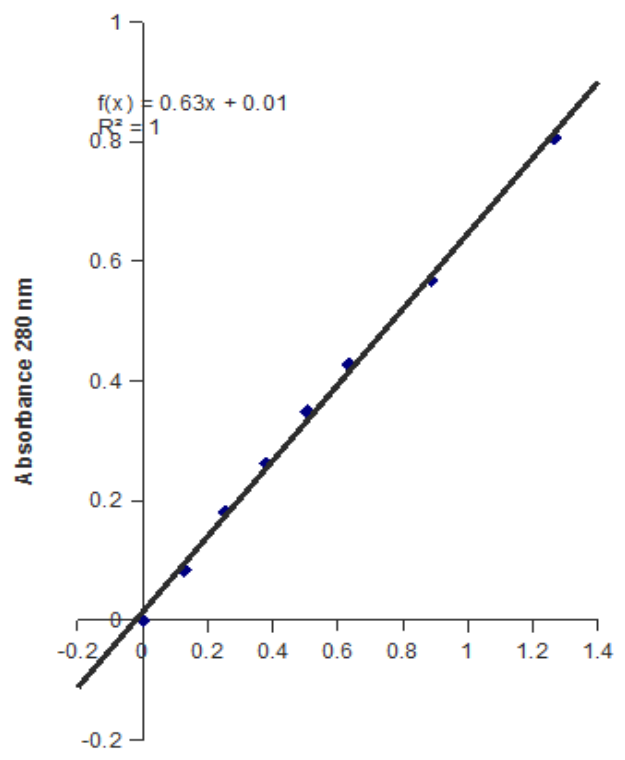

Figure 1: Bovine serum albumin protein standard curve

\section{Determination of the Fungal Viability}

The various fungal ghost preparations were investigated for the possibility of the presence of any viable cells by subjecting them to growth on Sabouraud's dextrose agar plates at $28^{\circ} \mathrm{C}$ for 7 days.

\section{Transmission Electron Microscope for Examination of A. niger Gs}

Transmission electron microscope (JEOL TEM 100 CX) was used for the examination of A. niger Gs.

\section{Agarose Gel Electrophoresis}

DNA in the supernatant for each randomization experiment was examined using agarose gel electrophoresis. $1 \%$ agarose gel containing $0.5 \mu \mathrm{g} / \mathrm{mL}$ ethidium bromide was run in a horizontal gel electrophoresis unit (Mini-Sub DNA cell, BioRad). The running buffer was TAE ( $40 \mathrm{mM}$ Tris, $20 \mathrm{mM}$ acetic acid, $1 \mathrm{mM}$ EDTA, pH 8.0). Electrophoresis was carried out at $100 \mathrm{~V}$ for $1 \mathrm{~h}$ on an Amersham-Pharmacia Biotech (Uppsala, Sweden) power supplier unit ECPS3000/150. The stained bands were visualized with UV light (309 nm) using a transilluminator, and the gel was recorded as digital image using a gel documentation system (UVITech).

\section{Polyacrylamide Gel Electrophoresis}

Protein in the supernatant for each randomization experiment was examined on $12 \%$ sodium dodecyl sulfate-polyacrylamide gel electrophoresis (SDS-PAGE). About $50 \mu \mathrm{l}$ of each sample were heated for $2-10 \mathrm{~min}$ at $100^{\circ} \mathrm{C}$ after the addition of $5 \mu \mathrm{l}$ of $5 \times$ loading buffer. Spin down for 1 second to remove debris and subjected to SDS-PAGE with a 0.5 -mm-thick gel in Invitrogen device Novex Minicell. Prestained marker heated at $95^{\circ} \mathrm{C}$ was used to calibrate protein mobility.

\section{Results and Discussion}

The production of microbial ghost cells is an aim for scientists as well as the isolation of DNA and protein. There are a large number of protocols for isolating and purifying DNA and protein. Each protocol is designed to match certain criteria and uses certain compounds in defined steps. Adding new idea concerning isolation of both DNA and protein will add new possibility and choices for different situations. The production of ghost cells is achieved by removing the cytoplasm from the microbial cells. The process is very sensitive but easy to conduct after determining both MIC and MGC. From the first step in the Sponge-like protocol, both DNA and protein were given special interest as parameters could be easily monitored spectrophotometrically and indicate microbial cells loss of them during cell cytoplasm loss. A. niger was used for first time to evaluate the Sponge-like protocol as a tool which is able to produce microbial ghosts and also could be adjusted to isolate DNA and protein.

As described earlier in the first protocol, the main feature that distinguishes this protocol from others was the determination of both MIC and MGC. An early work was done by introducing modifications in the plasmid alkaline lysis protocol via omitting the last step and adding the phenol extract step to turn it from plasmid isolation to DNA isolation protocol [29]. Such nonenzymatic DNA isolation protocol was used with different microbes and proves efficiency [29]. However, that study revealed variation in the prepared DNA quality as a fixed protocol was applied to different microbes that showed different responses to the used chemical compounds.

After improving the Sponge-Like protocol and proving its efficacy [15], it becomes clear that different microbes have different responses to the used chemicals and thus they show different MIC and MGC values. One of the benefits of this protocol that it can be used for strain differentiation rather than ghost cells preparation. Additionally, enzymes and proteins are able to introduce pores in the microbes when used at their MIC and MGC values [4, 22]. The white egg lysozyme was used to induce an emergence protocol for ghost cells preparation that could be used globally [22].

Our scientific group are working extensively to establish the Sponge-like protocol and to investigate the possibility of its use in DNA and protein preparation. This study is the first trial to prepare fungal ghost cells and investigate the possibility of DNA and protein isolation from fungal cells via Sponge-Like protocol. A. niger was selected as a representative fungus. The MIC and MGC values of different used chemicals were determined. $\mathrm{NaOH}, \mathrm{SDS}, \mathrm{H}_{2} \mathrm{O}_{2}$, and $\mathrm{NaHCO}_{3}$ showed MIC values of $0.01 \mathrm{~g} / \mathrm{mL}$, $0.0001 \mathrm{~g} / \mathrm{mL}, 0.3 \mathrm{~mL} / \mathrm{mL}$, and $0.01 \mathrm{~g} / \mathrm{mL}$, respectively, while gave 
MGC values of $0.001 \mathrm{~g} / \mathrm{mL}, 0.00001 \mathrm{~g} / \mathrm{mL}, 0.15 \mathrm{~mL} / \mathrm{mL}$, and 0.001 $\mathrm{g} / \mathrm{mL}$, respectively.

After determining MIC and MGC for such compounds against A. niger, five randomization experiments were conducted.Results of these randomization experiments are summarized in Table 2. Data from experiments number 2 and 3 in step one show high release for the protein due to the presence of SDS as +1 in both. In experiment number 3 , the culture cultivation temperature was $28^{\circ} \mathrm{C}$ which might be responsible for the slight increase in the released protein than in experiment number 2 .

In step two $\left(\mathrm{H}_{2} \mathrm{O}_{2}\right)$ in experiment number 3 , results still show high protein release and the same was in step 3. Experiments 4 and 5 in step one, there are no treatment differences but the amount of the released protein in experiment 4 is higher than experiment 5. The apparent explanation that in experiment 4, the cells are grown for a longer time (10 days) and for that they contain more protein. In experiments 4 and 5 in the second step still experiment number 4 has higher release to the protein for the same reason in addition to the high amount of the $\mathrm{H}_{2} \mathrm{O}_{2}$ might be responsible for the increase in the released protein. In experiment number one SDS was -1 for that it shows lower release to the protein than in experiments number 2 and 3 , however and due to the presence of shaking, its release is continuous in step 2 and 3. Considering the effect of the shaking rate as in experiments number 1 and 5 where the SDS was -1, apparently it induces the release of the protein from cells in the successive steps. $\mathrm{H}_{2} \mathrm{O}_{2}$ apparently not highly effective in the protein release as it was in its +1 at experiments number 1,3 and 4 but only experiment 3 shows the highest released protein due to the presence of the +1 SDS. Simultaneously, the effect of SDS on the released amount of DNA is clear in step 1 as experiments number 2 and 3 show the highest DNA release. The presence of $\mathrm{NaOH}$ and $\mathrm{NaHCO}_{3}$ in +1 , decreases the amount of the released DNA because they might cause degradation for it, that can be observed in step
1 at experiment 2 and $3 . \mathrm{H}_{2} \mathrm{O}_{2}$ in experiments number 2 and 5 shows the lower release which might be due to the degradation of the DNA where $\mathrm{NaOH}$ is present in its +1 which might have a synergistic effect with $\mathrm{H}_{2} \mathrm{O}_{2}$ to degrade DNA and in the absence of $\mathrm{NaOH}$ in experiment 3. The amount of the released DNA is more than the experiments number 2 and 5 . So in the same experiment $\left(\mathrm{No}_{3}\right)$ step 2 where $\mathrm{H}_{2} \mathrm{O}_{2}$ is -1 shows decrease in the amount of the DNA than step 1 which proves that $\mathrm{H}_{2} \mathrm{O}_{2}$ is a DNA-degrader. The Ethanol step still show variable release to each of the protein and the DNA according to the pores formed and the protein and the DNA still existe.

In experiments 1 and 5 where the shaking was +1 it might have negative effect on the cells quality. That might be explained by the fact that cells upon their losing to their cytoplasmic content also loss their rigidity.

The different experiments show different ghost cells quality as presented in Table 2. One should put in his consideration that the representative images are taken after the third step for each experiment which represent the final preparation. The quality was given as a percentage and calculated based on $20 \%$ for the appearance of clear nuclei in the hypha, $20 \%$ for the correct 3D structure of the hypha, $20 \%$ for the absence of the spores in the tested sample, $20 \%$ for the absence of the sporangia, and $20 \%$ for the general appearance of the sample.

Figure 2 summarizes the results of light microscope examination to prepared fungal ghost cells after each experiment. The wild type shows clear sporangia with well-differentiated spores and hyphae. The prepared fungal ghost cells in the five experiments lost the ability to produce the sporangia including the spores. Hyphae elongation was evident. The loss of the nuclei was observed clearly but in variable degrees. The samples were shaked during ghost cells preparation showed a sort of hyphal intertwining and shrinkage (Figure 2 images $d$ and $h$ ).

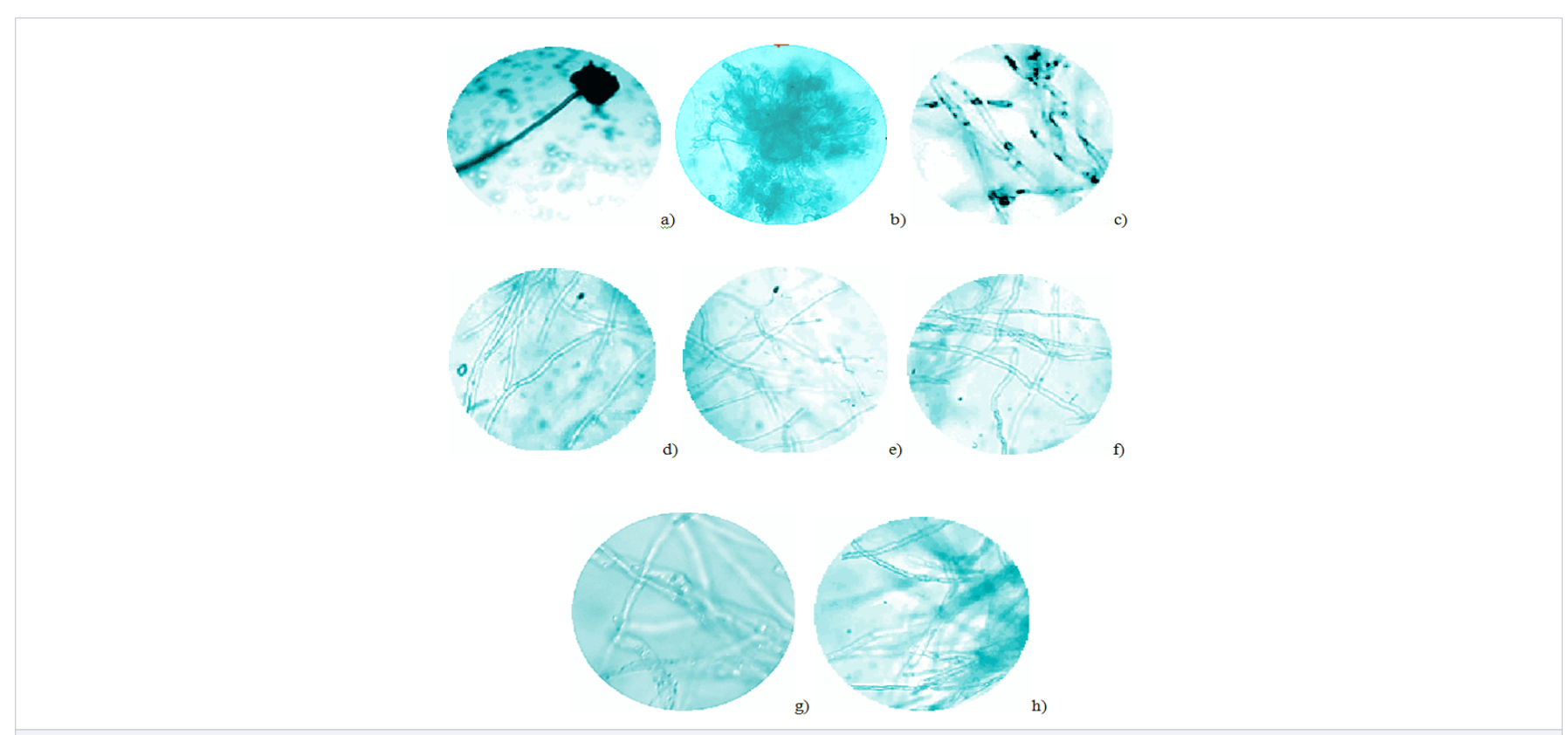

Figure 2: a) A. niger wild type untreated b) A. niger sporangia untreated c) A. niger hyhae untreated d) ghost cells from experiment 1 e) ghost cells from experiment $2 \mathrm{f}$ ) ghost cells from experiment $3 \mathrm{~g}$ ) ghost cells from experiment $4 \mathrm{~h}$ ) ghost cells from experiment 5

Citation: Amro AA, El-Baky NA, Mona MS, Amer E, et al. (2018) Protein and DNA Isolation from Aspergillus Niger as well as Ghost Cells Formation. SOJ Biochem 4(1):1-7. 
No growth was obtained on Sabouraud's dextrose agar plates after ghost cells cultivation from any of the five experiments which prove the loss of the cytoplasmic content during the process and the death of the fungus. However, the hyphae elongation was not definitely known to occur after which of the three steps of ghost cells preparation.

In conclusion, this study succeeded in fungal cell evacuation and ghost cells preparation releasing both DNA and protein content.

The examination by transmission electron microscope results in a clear prove for the evacuation of the analyzed samples. By comparing experiment 1 with experiment 3 as in Figure 3, the image 3a from experiment number 1 magnification of the section of A. niger cells at $1200 x$ represents less loss of A. niger cytoplasm while the image $3 \mathrm{~b}$ in experiment number 3 magnification of the section of $A$. niger cells at $1200 x$ the sample lost most of its cytoplasmic content. This does not agree with the results in Table 1 where experiment 1 gives $70 \%$ quality while experiment 3 gives $60 \%$ quality. Even if they are both near in their quality $\%$ however, electron microscope gives better judgement. Image $3 \mathrm{~b}$ shows better loss for the cytoplasmic content which proves the power of the Sponge-Like protocol in evacuating the microbes. Comparing image $3 \mathrm{c}$ which represents sample from experiment number 1 magnied at $10000 \mathrm{x}$ with image $3 \mathrm{~d}$ which represents sample from experiment number 5 magnied at $10000 x$, the result agrees with that in Table 2 where the quality of the experiment 1 was $70 \%$ and of experiment 5 was $55 \%$. The transmission electron microscope proves that the different preparation based on each experiment give different results, however, $A$. niger cells were turned to ghost cells. Some cells did not lose their cytoplasmic content however, they become nonviable as proved by the viability test. Those samples which show existence of the cytoplasm need more washing processes.

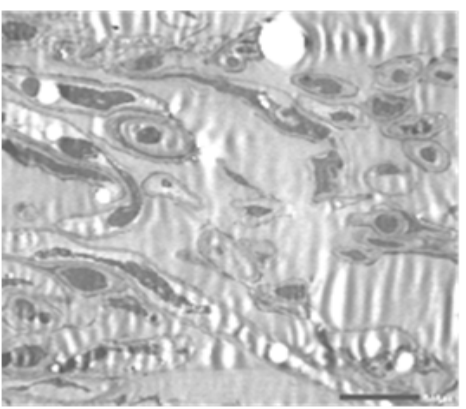

a)

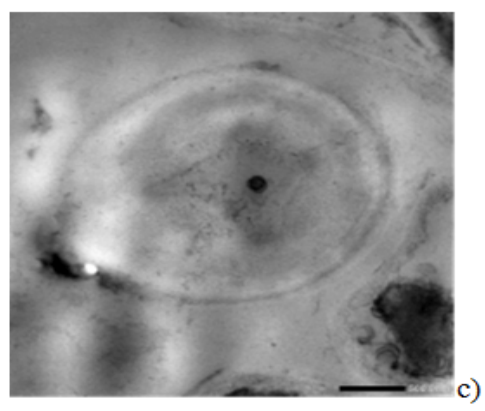

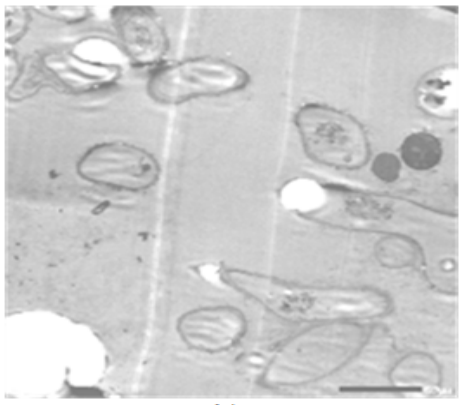

b)

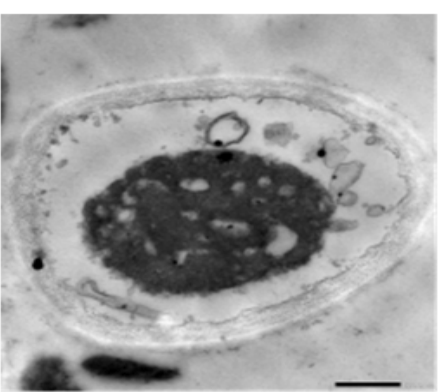

d)

Figure 3: The results of transmission electron microscope for A. niger different treatments and magnifications: a) Experiment number 1 magnification of the section of A. niger cells at 1200x; b) Experiment number 3 magnification of the section of A. niger cells at 1200x; c) Experiment number 1 magnification of the section of A. niger cells at 10000x; d) Experiment number 5 magnification of the section of A. niger cells at 10000x

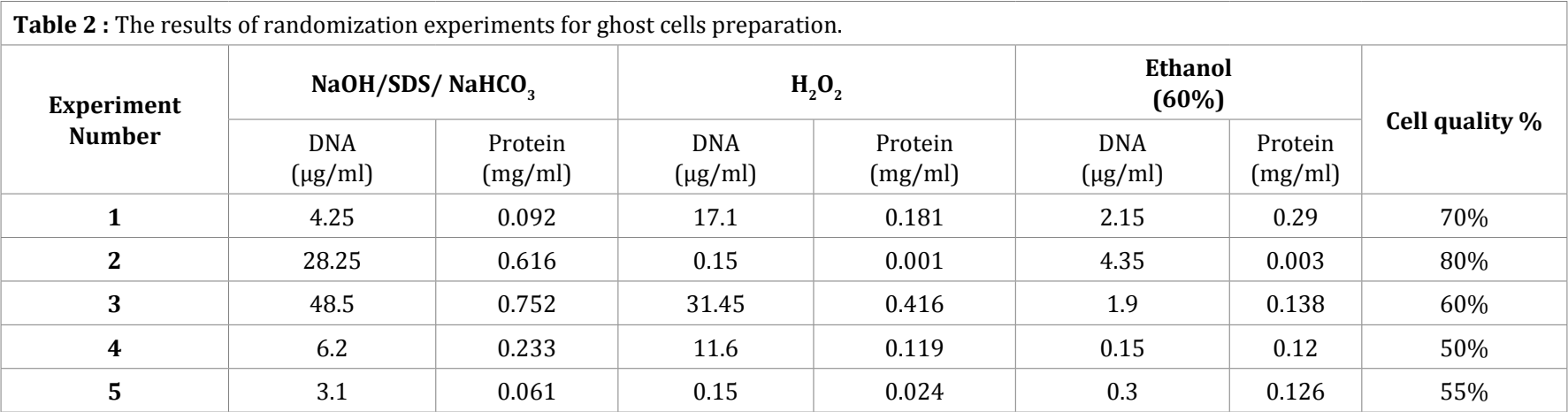


The SDS-PAGE analysis of the different samples supernatant prove the existence of protein in all supernatants of the five conducted experiments [Figure 4]. However, the samples represent the experiments end result which is another prove for the loss of the protein during the experiments steps. For obtaining better protein preparation, one should collect the protein of each step during each experiment and follow that with protein precipitation to concentrate the protein samples. The DNA agarose gel results which represent the end point of each of the five conducted experiments are the same [Figure 5, Figure 6]. The DNA from the samples were nearly removed. In addition, during the preparation steps more DNA in each sample is shown. The overall protocol succeeded to prepare $A$. niger as ghost cells and shows the first trial to prepare protein and DNA using the critical chemical concentration of the used compounds. One should not neglect the side effect of $\mathrm{H}_{2} \mathrm{O}_{2}$ on DNA which has been used in all of the experiments either with MIC or MGC but still effective. The data reveal more optimization is in need. The concept is clear, if MIC and MGC of the used chemical compounds are able to turn A. niger to ghost cells by inducing pores so the released DNA and cytoplasm can be collected. By improving such protocol, it will be a universal protocol for preparing both DNA and protein as well as ghost cells. In addition, other micro and macromolecules as well as different biological elements could be prepared.

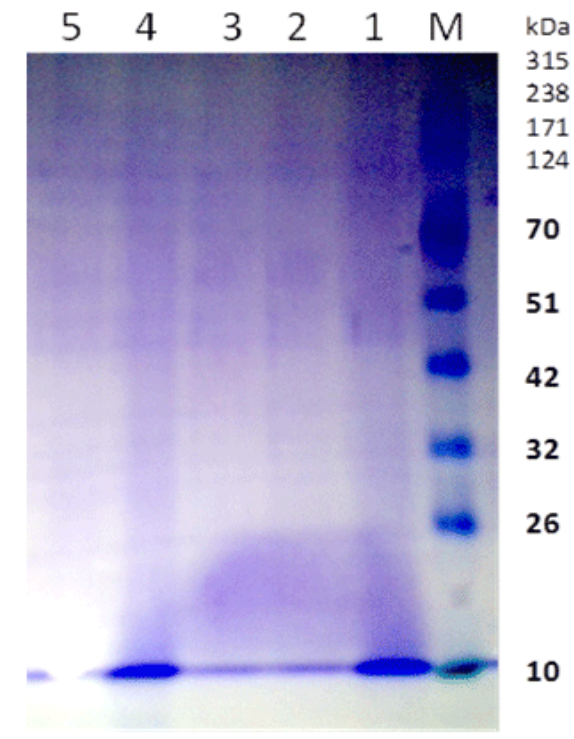

Figure 4: 12\% SDS-PAGE analysis of different experiments for $A$. niger ghost cells preparation. Lanes 1-5 represent supernatant from experiments 1 to 5 respectively for $A$. niger ghost cells preparation. M, represent protein marker

\section{Conflict of Interests}

The authors have no conflict of interests to declare.

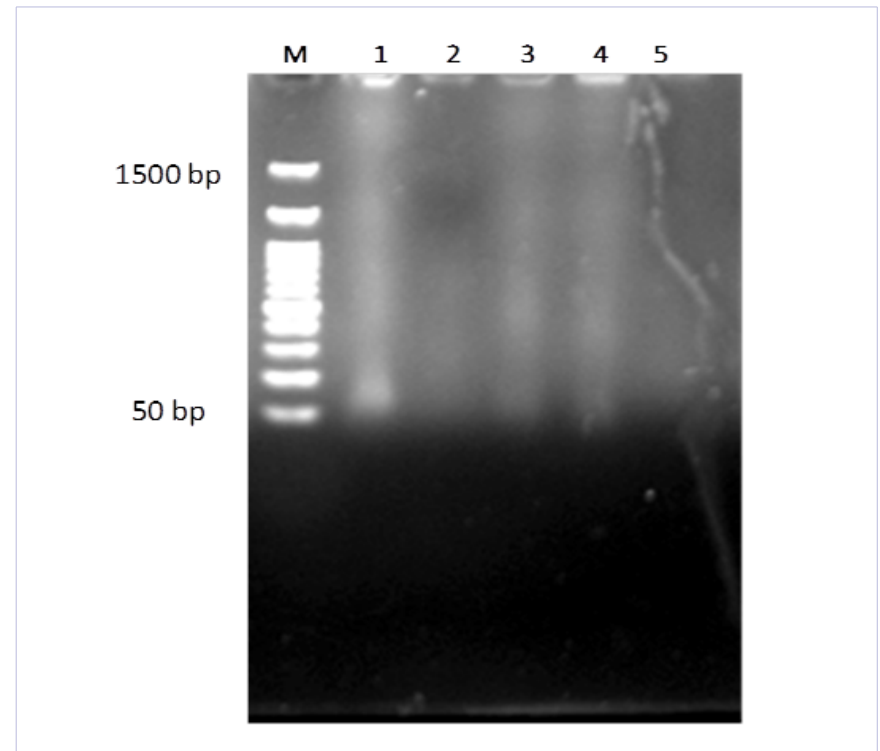

Figure 5: Agarose gel electrophoresis for A. niger ghost cells prepared in different experiments. DNA marker (lane M), A. niger during ghost preparation (lanes 1-5)

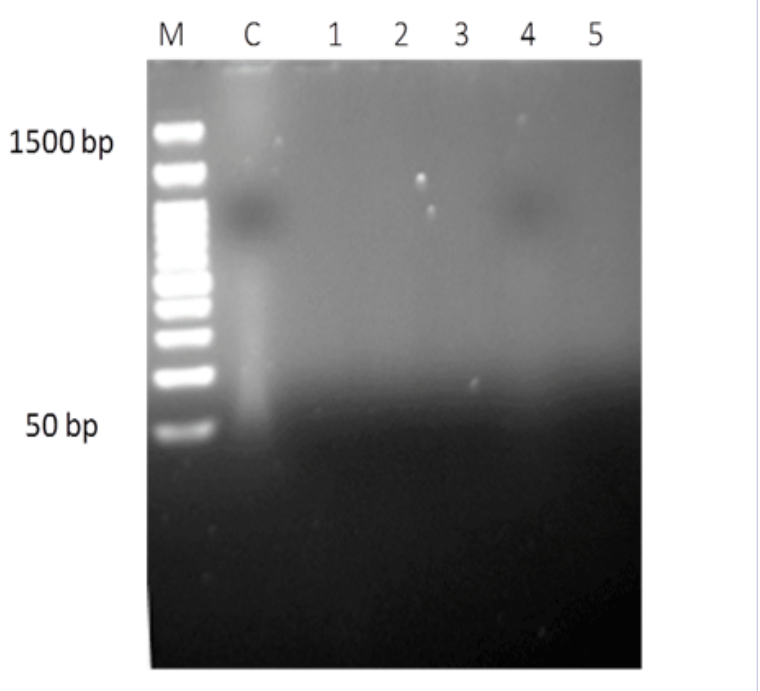

Figure 6: Agarose gel electrophoresis for $A$. niger ghost cells prepared at the end of different experiments. DNA marker (lane M); A. niger control (lane C); A. niger after ghost preparation (lanes 1-5).

\section{References}

1. Egbuta MA, Mwanza M, Babalola 00. A review of the ubiquity of Ascomycetes filamentous fungi in relation to their economic and medical importance. Advanced in Microbiology. 2016;6:1140-1158. DOI: $10.4236 /$ aim.2016.614103

2. Feldmesser M. Prospects of vaccines for medically important fungi. Medical Mycology. 2005;43(7):571-587.

3. Schuster E, D-N Coleman, Frisvad J, van Dijck P.On the safety of Aspergillus niger- A review. Applied microbiology and Biotechnology. 2002;59(4-5):426-435,DOI: 10.1007/s00253-002-1032-6 
4. Amara AA. Lysozymes, Proteinase K, Bacteriophage E Lysis Proteins, and some ChemicalPage 16 of 16 Compounds for MGs Preparation: a Review and Food for Thought. SOJ Biochem. 2016;2(1):1-16.

5. Dong H, Han X, Bai H, He L, Liu L, Liu R, et al. Mutation of lambdapL/ pR-cl857 system for production of bacterial ghost in Escherichia coli. Sheng wu gong cheng xue bao. Chinese journal of biotechnology. 2012;28(12):1423-1430.

6. Laemmli UK. Cleavage of structural proteins during the assembly of the head of bacteriophage T4. Nature. 1970;227:680-685.

7. Makino K, Yokoyama K, Kubota Y, Yutsudo CH, Kimura S, Kurokawa K, et al.Complete nucleotide sequence of the prophage VT2-Sakai carrying the verotoxin 2 genes of the enterohemorrhagic Escherichia coli 0157: H7 derived from the Sakai outbreak. Genes \& genetic systems. 1999;74(5):227-239.

8. Panthel K, Jechlinger W, Matis A, Rohde M, Szostak M, Lubitz W.Generation of Helicobacter pylori ghosts by PhiX protein E-mediated inactivation and their evaluation as vaccine candidates. Infect Immun. 2003;71:109-116.

9. Hensel A, Huter V, Katinger A, Raza P, Strnistschie C, Roesler U,et al.Intramuscular immunization with genetically inactivated (ghosts) Actinobacillus pleuropneumoniae serotype 9 protects pigs against homologous aerosol challenge and prevents carrier state. Vaccine. 2000;18(26):2945-2955.

10. Weibull C. The nature of the ghosts obtained by lysozyme lysis of Bacillus megaterium. Exp Cell Res. 1956;10(1):214-221.

11. Witte A, Wanner G, Sulzner M, Lubitz W. Dynamics of PhiX174 protein E-mediated lysis of Escherichia coli. Arch Microbiol. 1992;157:381388.

12. Amara AA, Salem-Bekhit, M.M., Alanazi, FK. Preparation of bacterial ghosts for E. coli JM 109 using: sponge-like reduced protocol. Asian J Biol Sci.2013; 6(8):363-369.

13. Amara AA, Salem-Bekhit,M. M., Alanazi,F K. 2013. Sponge-like: a new protocol for preparing Bacterial Ghosts. TSWJ.2013; Article ID 545741:1-8.

14. Amara AA. Saccharomyces cerevisiae Ghosts Using the Sponge-Like Re-Reduced Protocol SOJ Biochem. 2015:1-4.

15. Amara AA, Salem-Bekhit MM, Alanazi FK.Sponge-like: a new protocol for preparing bacterial ghosts. The Scientific World Journal. 2013;1-8.

16. Amara AA, Neama AJ, Hussein A, Hashish EA, Sheweita SA.Evaluation the surface antigen of the Salmonella typhimurium ATCC 14028 ghosts prepared by "SLRP”. Scientific World Journal .2014:840863. DOI: $10.1155 / 2014 / 840863$
17. El-Baky NA, Amara AA. Newcastle disease virus (LaSota strain) as a model for virus Ghosts preparation using $\mathrm{H} 2 \mathrm{O} 2$ bio-critical concentration. International Science and Investigation journal. 2014;3:38-50.

18. Vinod N, Oh S, Kim S, Choi CW, Kim SC, Jang CH. Chemically Induced Salmonella Enteritidis Ghosts as A novel Vaccine Candidate Against Virulent Challenge In Arat Model. Vaccine. 2014;32:3249-3255.

19. Amara AA. Bacterial and Yeast Ghosts: E. coli and Saccharomyces cerevisiae preparation as drug delivery model ISIJ Biochemistry.2015;4:11-22.

20. Amara AA. Kostenlos viral ghosts, bacterial ghosts microbial ghosts and more. Schuling Verlag - Germany. 2015

21. Vinod N, Oh S, Park HJ, Koo JM, Choi CW, Kim SC. Generation of a Novel Staphylococcus aureus Ghost Vaccine and Examination of Its Immunogenicity against Virulent Challenge in Rats. Infect Immun 2015; 83(7):2957-2965. DOI: 10.1128/IAI.00009-15

22. Amara AA. The critical activity for the cell all degrading enzymes: Could the use of the lysozyme for microbial ghosts preparation establish emergance oral vaccination protocol?. International Science and Investigation Journal 2016;5:351-369.

23. Amara AA. Vaccine against pathogens: A review and food for thought. SOJ Biochemistry. 2016;2:1-20.

24. Hussain ZM, Amra AA. Case-by-case study using antibiotic-EDTA combination to control Pseudomonas aeruginosa. Pak J Pharm Sci, 2016;19(3):236-243.

25. Park HJ, Oh S, Vinod N, Ji S,Noh HB, Koo JM et al. Characterization of Chemically-Induced Bacterial Ghosts (BGs) Using Sodium HydroxideInduced Vibrio parahaemolyticus Ghosts (VPGs). International Journal of Molecular Sciences. 2016;17(11):1904.

26. Wu X, Ju X, Du L, Yuan j, Wang L, He R, et al. Production of Bacterial Ghosts from Gram-Positive Pathogen Listeria monocytogenes. Foodborne Pathogens and Disease. 2017; 14(1):1-7.DOI: 10.1089/ fpd.2016.2184

27. Menisy MM,HA,Ghazy A, Sheweita S, Amara A A. Klebsiella pneumoniae Ghosts as Vaccine Using Sponge Like Reduced Protocol. Cellular and Molecular Medicine.2017;3(2):1-8. DOI: 10.21767/25735365.100034

28. Sambrook J , Fristch EF, Mainiatis T. Molecular Cloning a Laboratory Manual. Molecular cloning: a laboratory manual. Cold Spring Harbor. 1989. 2nd edition.

29. Amara AA, Afifi IK, Younis MM, Sharaf MM, Shabeb MS. Non-Enzymatic method for DNA preparation from different microbial strains. Egyptian Journal of Biotechnology. 2005;21:339-349. 